\title{
Karakteristik Pasien dengan Nodul Tiroid di Rumah Sakit X Bandung
}

\author{
Yuyun Saputri*, Meta Maulida Damayanti \\ Prodi Pendidikan Kedokteran, Fakultas Kedokteran, Universitas Islam \\ Bandung, Indonesia. \\ *saputriyuyun4@gmail.com,meta_md@unisba.ac.id
}

\begin{abstract}
Thyroid nodule is a disease that can be caused by various disorders. About $90 \%$ of thyroid nodules are benign and $10 \%$ are malignant. In Indonesian, statistical data for thyroid nodules are still limit. The porpose of this study was to collect the characteristics of patients with thyroid nodules at the X Hospital Bandung. This study used a observational descriptive method using total sampling technique. Data were obtained through medical records for January 2018-December 2019 at X Hospital and obtained 72 medical records that met the inclusion criteria. The results showed that the highest frequency based on age was found in the 40-49 years age group at $32 \%$. The highest frequency based on gender was found in female patients by $90 \%$. The highest frequency based on the size of thyroid nodules was found in the group $>4 \mathrm{~cm}$ at $72 \%$. The highest frequency based on histopathological features was found in adenomatoid goiter by $74 \%$. The conclusions in this study indicate that the highest frequency of thyroid nodules occurs at the age of 40-49 years, women, thyroid nodule size $>4 \mathrm{~cm}$ and adenomatoid goiter type. This happens because a person's immunity and body resistance decrease with age. In women, the risk of thyroid nodule disease can increase with the use of the hormone estrogen in oral contraceptives, in pregnancy and changes in the menstrual cycle.
\end{abstract}

Keywords: Age, Gender, Histopathological Feature, Nodule Size, Thyroid Nodules.

Abstrak. Nodul tiroid merupakan kasus yang dapat disebabkan oleh berbagai jenis gangguan kelenjar tiroid dan masih sering ditemukan. Sekitar $90 \%$ nodul tiroid bersifat jinak dan $10 \%$ bersifat ganas. Di Indonesia data statistik mengenai nodul tiroid masih sangat kurang. Penelitian ini bertujuan mengetahui karakteristik pasien dengan nodul. Penelitian ini menggunakan metode deskriptif observasional dengan pendekatan potong lintang. Teknik pengambilan sampel dalam penelitian ini adalah Total Sampling. Data didapatkan melalui rekam medis tahun 2018-2019 di Rumah Sakit X Bandung dan didapatkan 72 rekam medis yang memenuhi kriteria inklusi. Hasil penelitian menunjukkan frekuensi tertinggi berdasarkan usia terdapat pada kelompok usia 40-49 tahun sebesar $32 \%$. Frekuensi tertinggi berdasarkan jenis kelamin terdapat pada pasien perempuan sebesar $90 \%$. Frekuensi tertinggi berdasarkan ukuran nodul tiroid terdapat pada kelompok $>4 \mathrm{~cm}$ sebesar $72 \%$. Frekuensi tertinggi berdasarkan gambaran histopatologi terdapat pada adenomatoid goiter sebesar $74 \%$. Simpulan pada penelitian ini menunjukkan frekuensi tertinggi terjadinya nodul tiroid terdapat pada usia 40-49 tahun, perempuan, ukuran nodul tiroid $>4 \mathrm{~cm}$ dan jenis adenomatoid goiter. Hal ini terjadi karena imunitas dan daya tahan tubuh seseorang menjadi menurun seiring bertambahnya usia. Pada perempuan risiko penyakit nodul tiroid dapat meningkat dengan penggunaan hormon estrogen pada kontrasepsi oral, pada kehamilan serta perubahan siklus menstruasi.

Kata Kunci: Gambaran Histopatologi, Jenis Kelamin, Nodul Tiroid, Ukuran Nodul, Usia. 


\section{A. Pendahuluan}

Nodul tiroid merupakan kasus yang sering ditemukan dan dapat disebabkan oleh berbagai jenis gangguan pada kelenjar tiroid. Sekitar $90 \%$ nodul tiroid bersifat jinak dan $10 \%$ bersifat ganas. Sebagaian kasus, nodul tiroid dapat berubah menjadi suatu keganasan walaupun angka kejadiannya relative rendah yaitu $5-10 \%$. Nodul tiroid yang jinak tidak mengganggu fungsi dan aktivitas bagian tubuh lainnya, sedangkan pada nodul tiroid yang ganas dapat mengganggu fungsi tubuh dan dapat menyebar keseluruh tubuh secara sporadik sehingga dapat menyebabkan kematian.

Di Amerika Serikat, ditemukan sekitar 16 juta orang yang mengalami pembesaran pada kelenjar tiroid, sekitar 63.000 kasus baru kanker tiroid terjadi di tahun 2014. Angka yang lebih tinggi dibandingkan dengan tahun 2009 yang mencapai 37.200. Terdapat sekitar 1.890 angka kematian yang diakibatkan karena kanker tiroid. Di Indonesia data statistik mengenai nodul tiroid masih sangat kurang, tetapi menurut kementerian kesehatan dari data Sistem Informasi Rumah Sakit (SIRS) tahun 2015 jumlah kasus tertinggi gangguan tiroid di Indonesia berada di provinsi Sumatera Selatan yang mencapai 1.400 kasus. Di Jawa Barat kasus gangguan tiroid mencapai sekitar 1.100 kasus yang merupakan kasus tertinggi ke-3 setelah Sumatera Selatan dan Jawa Tengah.

Studi epidemiologis telah mengindikasikan bahwa sekitar 5\% wanita dan $1 \%$ pria yang tinggal di daerah cukup yodium memiliki nodul tiroid yang dapat teraba. Namun, pada usia 60 tahun sekitar $50 \%$ dari populasi umum diperkirakan memiliki setidaknya satu nodul tiroid. Risiko nodul tiroid akan meningkat seiring bertambahnya usia dan kurangnya asupan sodium menjadi faktor pemicu nodul tiroid. Selain itu, paparan radiasi juga menjadi faktor pemicu tumbuhnya nodul tiroid dan juga menjadi faktor risiko berubahnya nodul tiroid menjadi suatu keganasan. Pada karsinoma tiroid terdapat beberapa faktor prognostik selain dari usia dan jenis kelamin, ukuran nodul juga merupakan prediktor independen pada prognosis. Berdasarkan gambaran histopatologi karsinoma tiroid tipe papilar, anaplastik, medular, dan folikular diperkirakan menduduki 90\% dari seluruh kasus keganasan tiroid.

Berbagai modalitas dalam menegakkan diagnosis pasti nodul tiroid dan untuk mengetahui jenisnya telah dikenal dalam dunia kesehatan. Mulai dari anamnesis sederhana, pemeriksaan fisik, hingga pemeriksaan penunjang seperti scan tiroid, tiroid tes fungsi Fine Needle Aspiration Cytology (FNAC) dan histopatologi dapat dipergunakan dalam penanganan pasien dengan nodul tiroid serta sebagai gold standar dari pemeriksaan penunjang. Pemeriksaan yang dilakukan terlebih dahulu adalah kadar Thyroid Stimulating Hormon (TSH). Bila didapat nilai TSH abnormal, dapat dilanjutkan dengan pemeriksaan T3 bebas dan kadar T4 bebas. Pemeriksaan Tiroglobulin biasanya tidak diperiksa sejak awal karena tidak dapat membedakan antara tumor jinak atau ganas, kecuali ketika terjadi peningkatan kadar tiroglobulin secara berlebih.

Konsensus dari Society of Radiologists in Ultrasound menyatakan nodul berukuran lebih dari $2 \mathrm{~cm}$ dapat dicurigai sebagai suatu keganasan dan dianjurkan untuk dilakukan pemeriksaan fine needle Biopsy (FNAB). Menurut panduan tatalaksana American Association of Clinical Endocrinologist, American college of Endocrinology, dan Associazione Medici Endocrinologi, nodul tiroid $<5 \mathrm{~mm}$ harus selalu dipantau dengan ultrasonografi daripada biopsi. Fine needle aspiration (FNA) pada pasien nodul tiroid dengan diameter $\leq 5-10 \mathrm{~mm}$ harus dipertimbangkan lagi, FNA dapat dilakukan ketika terdapat tanda-tanda yang lebih serius. FNA harus dilakukan pada nodul $>10 \mathrm{~mm}$.

Hasil penelitian sebelumnya yang dilakukan oleh Anggraini Tiara menunjukkan dari 71 kasus nodul tiroid di Rumah Sakit X Bandung periode 2017 memiliki karakteristik usia antara 36-45, dengan jenis kelamin tertinggi adalah perempuan dan gambaran histopatologi tersering adalah adenomatous goiter. Berdasarkan uraian di atas menunjukkan bahwa insidensi faktor risiko nodul tiroid tergantung dari usia dan jenis kelamin. Ukuran nodul merupakan prediktor independen pada prognosis dan juga dapat mendeteksi keganasan dari nodul tiroid tersebut. Diagnosa histopatologi yang merupakan gold standar dari jenis pemeriksaan penunjang yang dilakukan dalam menegakkan diagnosis nodul tiroid, maka dari itu peneliti tertarik untuk melakukan penelitian lebih lanjut yang bertujuan untuk mengetahui karakteristik pasien dengan 
nodul tiroid di rumah sakit $\mathrm{X}$ berdasarkan usia, jenis kelamin, ukuran nodul dan gambaran histopatologi.

\section{B. Metodologi Penelitian}

Penelitian ini menggunakan metode deskriptif observasional dengan pendekatan potong lintang dengan menggunakan teknik pengambilan sampel dalam penelitian ini adalah total sampling. Pengumpulan sampel dilakukan dengan menggunakan data sekunder yang diperoleh dari pencatatan pada rekam medis pasien Rumah Sakit X Bandung. Rekam medis pasien dengan nodul tiroid yang dipilih sebagai sampel, dikumpul dan dilakukan pencatatan tabulasi sesuai dengan variabel yang akan diteliti. Penelitian ini telah melalui kajian etika oleh Komite Etik Penelitian Kesehatan Fakultas Kedokteran Universitas Islam Bandung dengan nomor surat: 062/KEPK-Unisba/X/2020 dan persetujuan izin penelitian dari RSUD X Provinsi Jawa Barat dengan nomor surat: 070/1879/Diklit.RS.Ihsan.

\subsection{Definisi Operasional Variabel}

Tabel 3.1 Definisi Operasional Variabel

\begin{tabular}{|c|c|c|c|c|}
\hline Variabel & $\begin{array}{c}\text { Definisi } \\
\text { Operasional }\end{array}$ & $\begin{array}{l}\text { Alat } \\
\text { Ukur }\end{array}$ & Hasil Ukur & Skala Ukur \\
\hline Usia & $\begin{array}{l}\text { Usia yang tercatat } \\
\text { dalam rekam medis } \\
\text { pasien yang } \\
\text { mengalami } \\
\text { kelainan nodul } \\
\text { tiroid }\end{array}$ & $\begin{array}{l}\text { Rekam } \\
\text { medis }\end{array}$ & $\begin{array}{l}\text { 0-9 tahun } \\
\text { 10-19 tahun } \\
\text { 20-29 tahun } \\
\text { 30-39 tahun } \\
40-49 \text { tahun } \\
\text { 50-59 tahun } \\
\text { 60-69 tahun } \\
70-79 \text { tahun } \\
\geq 80 \text { tahun }\end{array}$ & $\begin{array}{l}\text { Kategorik } \\
\text { Nominal }\end{array}$ \\
\hline Jenis Kelamin & $\begin{array}{l}\text { Perbedaan jenis } \\
\text { kelamin dari pasien } \\
\text { sesuai dengan yang } \\
\text { tercatat dalam } \\
\text { rekam medis }\end{array}$ & $\begin{array}{l}\text { Rekam } \\
\text { medis }\end{array}$ & $\begin{array}{l}\text { Perempuan } \\
\text { Laki-laki }\end{array}$ & $\begin{array}{l}\text { Kategorik } \\
\text { Ordinal }\end{array}$ \\
\hline Ukuran Nodul & $\begin{array}{l}\text { Ukuran nodul } \\
\text { tiroid pasien yang } \\
\text { mengalami } \\
\text { kelainan nodul } \\
\text { tiroid }\end{array}$ & $\begin{array}{l}\text { Rekam } \\
\text { medis }\end{array}$ & $\begin{array}{l}<0,5 \mathrm{~cm} \\
>0,5-1 \mathrm{~cm} \\
>1 \mathrm{~cm}-2 \mathrm{~cm} \\
>2-4 \mathrm{~cm} \\
>4 \mathrm{~cm}\end{array}$ & $\begin{array}{l}\text { Kategorik } \\
\text { Nominal }\end{array}$ \\
\hline
\end{tabular}


74 | Yuyun Saputri, et al.

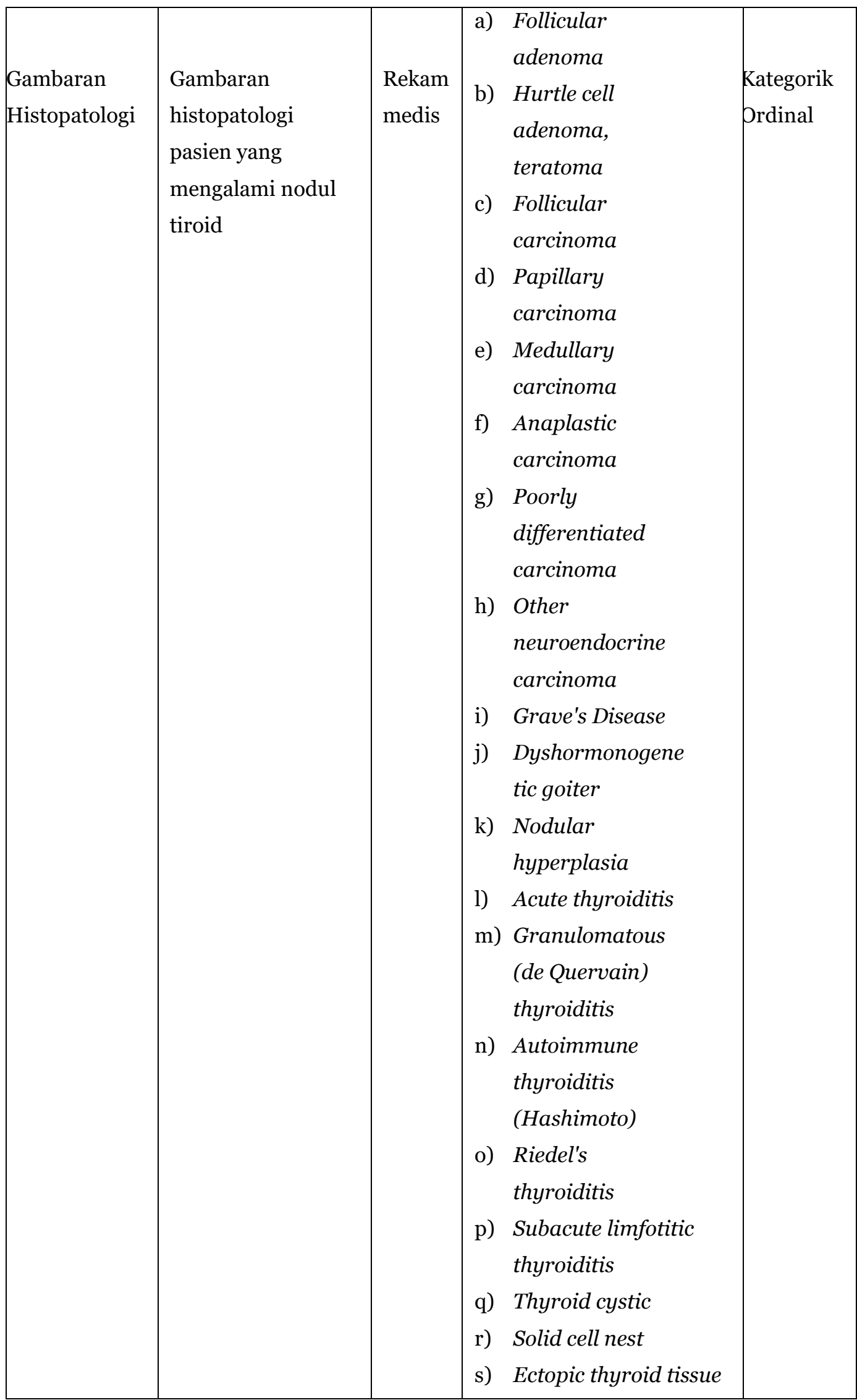




\section{Hasil Penelitian dan Pembahasan}

Penelitian tentang karakteristik pasien dengan nodul tiroid di Rumah Sakit X Bandung periode Januari 2018-Desember 2019. Penelitian ini menggunakan metode deskriptif observasional dengan pendekatan potong lintang yang melihat berdasarkan data sekunder melalui rekam medis pasien. Penelitian ini ingin mengetahui karakteristik penderita nodul tiroid berdasarkan usia, jenis kelamin, ukuran nodul dan gambaran histopatologi. Dari hasil penelitian ditemukan bahwa pasien dengan nodul tiroid di Rumah Sakit X Bandung periode Januari 2018-Desember 2019 yang memenuhi kriteria inklusi sebanyak 72 kasus. Adapun hasil penelitiannya disajikan dalam bentuk tabel sebagai berikut:

Tabel 4.1 Distribusi Penderita Nodul Tiroid Berdasarkan Usia

\begin{tabular}{lcc}
\hline \multicolumn{1}{c}{ Usia } & Jumlah (n) & Persentasi (\%) \\
\hline 0-9 tahun & 0 & 0 \\
10-19 tahun & 0 & 0 \\
20-29 tahun & 8 & 11 \\
30-39 tahun & 13 & 18 \\
40-49 tahun & 23 & 32 \\
50-59 tahun & 17 & 24 \\
60-69 tahun & 8 & 11 \\
70-79 tahun & 3 & 4 \\
$\geq 80$ tahun & 0 & 0 \\
Total & 72 & 100 \\
\hline
\end{tabular}

Berdasarkan Tabel 4.1 dapat diketahui bahwa dari 72 penderita nodul tiroid di Rumah Sakit X Bandung frekuensi tertinggi berdasarkan usia terdapat pada usia 40-49 tahun sebanyak 23 pasien atau sebesar $32 \%$.

Tabel 4.2 Distribusi Penderita Nodul Tiroid Berdasarkan Jenis Kelamin

\begin{tabular}{lcc}
\hline $\begin{array}{c}\text { Jenis } \\
\text { Kelamin }\end{array}$ & Jumlah (n) & Persentasi (\%) \\
\hline Laki- laki & 7 & 10 \\
Perempuan & 65 & 90 \\
Total & 72 & 100 \\
\hline
\end{tabular}

Berdasarkan Tabel 4.2 dapat diketahui bahwa dari 72 penderita nodul tiroid di Rumah Sakit X Bandung frekuensi tertinggi berdasarkan jenis kelamin penderita nodul tiroid secara epidemiologi lebih banyak perempuan yaitu sebanyak 65 pasien atau sebesar $90 \%$ dibandingkan dengan laki-laki hanya terdapat 7 pasien atau $10 \%$.

Tabel 4.3 Distribusi Penderita Nodul Tiroid Berdasarkan Ukuran Nodul 


\begin{tabular}{lcc}
\hline $\begin{array}{c}\text { Ukuran } \\
\text { Nodul }\end{array}$ & Jumlah (n) & Persentasi (\%) \\
\hline$<0,5 \mathrm{~cm}$ & 0 & 0 \\
$>0,5-1 \mathrm{~cm}$ & 0 & 0 \\
$>1-2 \mathrm{~cm}$ & 3 & 4 \\
$>2-4 \mathrm{~cm}$ & 17 & 24 \\
$>4 \mathrm{~cm}$ & 52 & 72 \\
Total & 72 & 100 \\
\hline
\end{tabular}

Berdasarkan Tabel 3 dapat diketahui bahwa dari 72 penderita nodul tiroid di Rumah Sakit $\mathrm{X}$ Bandung frekuensi tertinggi berdasarkan ukuran nodul tiroid terdapat pada kelompok $>4 \mathrm{~cm}$ yaitu sebanyak 52 pasien atau $72 \%$.

Tabel 4.4 Distribusi Penderita Nodul Tiroid Berdasarkan Gambaran Histopatologi

\begin{tabular}{|c|c|c|}
\hline Gambaran Histopatologi & Jumlah (n) & Persentase (\%) \\
\hline Follicular adenoma & 6 & 8 \\
\hline Hurtle cell adenoma, teratoma & o & o \\
\hline Follicular carcinoma & 1 & 1 \\
\hline Papillary carcinoma & 8 & 11 \\
\hline Medullary carcinoma & o & o \\
\hline Anaplastic carcinoma & o & o \\
\hline Squamous cell carcinoma & 1 & 1 \\
\hline Poorly differentiated carcinoma & 1 & 1 \\
\hline Other neuroendocrine tumors & o & o \\
\hline Grave's Disease & o & o \\
\hline Dyshormonogenetic goiter & o & o \\
\hline Adenomatoid goiter & 54 & 75 \\
\hline Acute thyroiditis & o & o \\
\hline $\begin{array}{l}\text { Granulomatous (de Quervain) } \\
\text { thyroiditis }\end{array}$ & o & o \\
\hline Autoimmune thyroiditis (Hashimoto) & 1 & 1 \\
\hline Riedel's thyroiditis & o & o \\
\hline
\end{tabular}


Subacute limfotitic thyroiditis

Thyroid cystic

Solid cell nest

Ectopic thyroid tissue

Total o

o

o

o

72 o

o

o

o

100

Berdasarkan Tabel 4.4 dapat diketahui bahwa dari 72 penderita nodul tiroid di Rumah Sakit X Bandung frekuensi tertinggi berdasarkan gambaran histopatologi terdapat pada kelompok adenomatous hiperplasia atau adenomatoid goiter yaitu sebanyak 54 pasien atau sebesar $75 \%$.

Berdasarkan hasil penelitian tentang karakteristik pasien dengan nodul tiroid di Rumah Sakit X Bandung periode Januari 2018-Desember 2019, diperoleh distribusi frekuensi berdasarkan usia, jenis kelamin, ukuran nodul dan gambaran histopatologi sebagai berikut:

1. Penderita Nodul Tiroid Berdasarkan Usia

Menurut hasil penelitian di Rumah Sakit X Bandung periode Januari 2018-Desember 2019 dari 72 pasien dengan nodul tiroid ditemukan berdasarkan karakteristik usia banyak terjadi pada kelompok usia 40-49 tahun yaitu sebanyak 23 orang atau sebesar $32 \%$. Dari penelitian ini, usia pasien yang mengalami nodul tiroid dimulai dari usia dewasa sampai usia tua. Hal ini terjadi karena imunitas dan daya tahan tubuh seseorang menjadi menurun seiring bertambahnya usia ditambah dengan meningkatnya kebutuhan yodium. Pada penelitian ini terdapat kesamaan dengan penelitian ucik dkk. yang mengatakan bahwa di RSUD Dr. Soetomo Surabaya tahun 2015 didapatkan dari 223 pasien dengan nodul tiroid banyak terjadi pada usia 40-49 tahun yaitu 26\%. Secara populasi terdapat kesamaan dan berbeda dengan hasil proporsi dari penelitian tersebut. Demikian juga dengan penelitian yang dilakukan oleh Lina Marlina tahun 2015 di Rumah Sakit Hasan Sadikin Bandung didapatkan dari 40 sampel pasien dengan nodul tiroid terbanyak terjadi pada usia 41-50 tahun yaitu 20 kasus sekitar 50\%. Hal ini dikarenakan semakin bertambahnya usia akan menyebabkan berkurangnya hormon tirosin yang dihasilkan oleh kelenjar tiroid sehingga kelenjar tiroid harus bekerja ekstra dalam memproduksi hormon. Kekurangan hormon tirosin dapat menyebabkan kelenjar hipofisis anterior mensekresikan TSH dalam jumlah berlebihan. TSH kemudian menyebabkan sel-sel tiroid mensekresikan tiroglobulin dalam jumlah besar kedalam folikel dan menyebabkan kelenjar tiroid menjadi bertambah besar.

2. Penderita Nodul Tiroid Berdasarkan Jenis Kelamin

Menurut hasil penelitian di Rumah Sakit X Bandung periode Januari 2018-Desember 2019 dari 72 pasien dengan nodul tiroid berdasarkan karakteristik jenis kelamin, banyak terjadi pada perempuan yaitu 65 orang atau sebesar $90 \%$. Hal ini terjadi karena risiko penyakit nodul tiroid pada wanita dapat semakin meningkat dengan penggunaan hormon estrogen eksogen pada kontrasepsi oral, pada kehamilan serta perubahan siklus menstruasi. Hal ini sejalan dengan penelitian yang dilakukan oleh Intan Damaya dkk. (2019) di RSUD Dr. H. Abdul Moeloek Bandar Lampung yang menunjukkan dari 49 pasien dengan nodul tiroid berdasarkan karakteristik jenis kelamin, perempuan lebih banyak dibandingkan laki-laki yaitu 81,6\%. Hal ini terjadi karena hormon estrogen pada wanita sangat berpengaruh atau merupakan salah satu faktor predisposisi yang menyebabkan jumlah nodul tiroid pada wanita lebih banyak dibandingkan laki-laki. Hormon estrogen dapat merangsang hipotalamus untuk mensekresikan Thyrotrophin Releasing Hormone (TRH) dan dapat meningkatkan kadar Thyroid Binding Globulin (TBG) yang bekerja untuk transpor T4 dan T3 dalam darah yang menyebabkan terjadinya penurunan kadar T4 bebas dan T3 bebas sehingga akan merangsang kelenjar hipofisis anterior untuk mensekresikan TSH yang dapat menyebabkan kelenjar tiroid 
mengalami pembesaran atau hiperplasia.

3. Penderita Nodul Tiroid Berdasarkan Ukuran Nodul

Menurut hasil penelitian di Rumah Sakit X Bandung periode Januari 2018-Desember 2019 dari 72 pasien dengan nodul tiroid ditemukan berdasarkan ukuran nodul tiroid tertinggi terdapat pada kelompok $>4 \mathrm{~cm}$ yaitu sebanyak 52 pasien atau $72 \%$. Hal ini terjadi karena pada pemeriksaan palpasi nodul tiroid yang berdiameter kurang dari $1 \mathrm{~cm}$ biasanya tidak dapat teraba dan nodul tiroid yang besar lebih mudah diraba. Hal ini sejalan dengan hasil penelitian yang dilakukan oleh Yohanes dkk. (2014) di RSUP Dr. Kariadi Semarang yang menunjukkan dari 88 pasien dengan nodul tiroid, terdapat 47 pasien yang memiliki ukuran nodul tiroid $>4 \mathrm{~cm}$ atau sebesar 53,4\%. Hal ini sejalan dengan hasil penelitian yang dilakukan oleh Yosep dkk. (2015) di RSUP Sanglah Denpasar yang menunjukkan dari 54 pasien dengan nodul tiroid, terdapat 35 pasien dengan ukuran nodul tiroid $>1 \mathrm{~cm}$ atau sebesar $64,8 \%$. Secara populasi terdapat kesamaan dan berbeda dengan hasil proporsi dari penelitian tersebut. Hal ini dikarenakan secara klinis ukuran dari nodul tiroid khususnya pada keganasan mengalami progresifitas sehingga ukuran lebih nodul $>4 \mathrm{~cm}$.

4. Penderita Nodul Tiroid Berdasarkan Gambaran Histopatologi

Menurut hasil penelitian di Rumah Sakit X Bandung periode Januari 2018-Desember 2019 dari 72 pasien dengan nodul tiroid ditemukan berdasarkan karakteristik gambaran histopatologi banyak terjadi pada kelompok adematous hiperplasia atau adenomatoid goiter yaitu sebanyak 54 pasien atau sebesar $75 \%$. Penyakit tiroid ini merupakan penyakit umum yang sering terjadi, secara tradisional dikenal sebagai endemik goiter yang sering terjadi didaerah pengunungan dan disebabkan karena kandungan yodium yang rendah. Defisiensi yodium dapat menghambat pembentukan hormon tiroid yang memungkinkan hipofisis anterior mensekresikan TSH dalam jumlah berlebihan. TSH kemudian menyebabkan sel-sel tiroid mensekresikan tiroglobulin dalam jumlah besar kedalam folikel dan menyebabkan kelenjar menjadi bertambah besar. Hal ini sejalan dengan penelitian yang dilakukan oleh Fransiskus dkk di Departemen/SMF THT-KL RSHS Bandung tahun 2016 didapatkan data 121 sampel penelitian yang terdiagnosis nodul tiroid paling banyak pada kelompok adenomatoid goiter yaitu sebesar $31 \%$. Selain itu penelitian ini juga sejalan dengan penelitian Amalia Pradanti di RS dr. Saiful Malang tahun 2015 didapatkan data 984 pasien dengan nodul tiroid berdasarkan karakteristik histopatologi banyak terjadi pada adenomatoid goiter yaitu sebesar 46\%. Penelitian selanjutnya yang sejalan dengan penelitian ini adalah penelitian yang dilakukan oleh Anggraini Tiara di Rumah Sakit X Bandung tahun 2017 didapatkan data 71 pasien dengan nodul tiroid berdasarkan karakteristik gambaran histopatologi banyak terjadi pada kelompok adenomatous goiter yaitu sebesar $70 \%$.

\section{Keterbatasan}

Banyak rekam medis yang terisi tidak lengkap terutama dibagian ukuran nodul tiroid dan gambaran histopatologi atau tidak sesuai dengan kriteria inklusi. Sehingga harus dilakukan penelusuran lebih lanjut ke bagian laboratorium untuk memastikan hasil ukuran nodul tiroid dan gambaran histopatologinya.

\section{Kesimpulan}

Kelompok usia pasien dengan nodul tiroid yang jumlahnya tertinggi adalah 40-49 tahun. Pasien dengan nodul tiroid berjenis kelamin perempuan lebih banyak daripada laki-laki. Ukuran penderita nodul tiroid tertinggi adalah $>4 \mathrm{~cm}$. Gambaran histopatologi penderita nodul tiroid yang paling banyak ditemukan adalah adenomatoid goiter.

\section{Acknowledge}

Penulis mengucapkan terima kasih kepada yang terhormat Dekan Fakultas Kedokteran Universitas Islam Bandung dan semua pihak yang terlibat dalam penelitian ini. 


\section{Daftar Pustaka}

[1] Yonathan, Tubagus VN, Ali RH. Gambaran USG pada pasien nodul tiroid di bagian/SMF radiologi FK Unsrat RSUP Prof Dr. R. D. Kandou Manado periode Juni 2016-Mei 2017. Jurnal e-Clinic. 2017;5(2):137-40.

[2] Trihadi N, Pemayun T. Ciri-ciri karakteristik penderita nodul tiroid di poliklinik endokrin dan poliklinik bedah RSUP Dr. Kariadi Semarang. Jurnal Kedokteran Diponegoro. 2014;3(1):3-5.

[3] Parura Y, Pontoh V, Werung M. Pola kanker tiroid periode Juli 2013-Juni 2016 di RSUP Prof. Dr. R. D Kandou Manado. Jurnal e-Clinic. 2016;4(2): 96-8.

[4] Haugen BR, Alexander EK, Bible KC, Doherty GM, Mandel SJ, Nikiforov YE, et al. 2015 American thyroid association management guidelines for adult patients with thyroid nodules and differentiated thyroid cancer: The american thyroid association guidelines task force on thyroid nodules and differentiated thyroid cancer. 2016;26(1):89-69.

[5] Bianco AC, Anderson G, Forrest D, Galton VA, Gereben B, Kim BW, et al. American thyroid association guide to investigating thyroid hormone economy and action in rodent and cell models. Thyroid. 2014;24(1):88-91.

[6] Kementrian Kesehatan RI. Profil penyakit tidak menular tahun 2016. Jakarta. Kemenkes RI. 2017:44-6.

[7] Paschou S, Vryonidou A, Goulis DG. Thyroid nodules: A guide to assessment, treatment and follow-up. Maturitas. 2017;96(1):8-9.

[8] Darmayanti NLA, Setiawan IGB, Maliawan S. Endemik goiter.E-Jurnal Medika Udayana. 2012;1(1):34-6.

[9] Lamb B, Green JSA, Vincent C, Sevdalis N. Decision making in surgical oncology. Surgical Oncology. 2011 Sep;20(3):163-8.

[10] Cardia P, Martadiani E, Sitanggang P. Karakteristik ultrasonografi pada kecurigaan klinis kanker tiroid di RSUP Sanglah Denpasar periode Januari 2015-Desember 2015. E-Jurnal Medika Udayana. 2020;9(9):76-9.

[11] Gharib H, Papini E, Garber JR, Duick DS, Harrell RM, Hegedüs L, et al. American association of clinical endocrinologists, american college of endocrinology, and associazione medici endocrinologi medical guidelines for clinical practice for the diagnosis and management of thyroid nodules-2016 update. Endocrine Practice. 2016;2(17):1-4.

[12] Setiati S, Alwi I, Sudoyo AW, Simadibrata M SS, Setiyohadi B, Fahrial A. Nodul tiroid. Ilmu penyakit dalam. Edisi ke-6 Jilid II. Jakarta: Interna Publishing; 2014. hlm. 2455-9.

[13] Kurniawan ARY, Idris N, Ilyas M, Liyadi F. Korelasi ultrasonografi nodul tiroid tirads dengan hasil histopatologi pada penderita struma noduler. Fak Univ Hasanudin. 2013.

[14] Chindris AM, Casler JD, Bernet VJ, Rivera M, Thomas C, Kachergus JM, et al. Clinical and molecular features of hürthle cell carcinoma of the thyroid. J Clin Endocrinol Metab. 2015;100(1):55-62.

[15] Prapyatiningsih Y, Ardika Nuaba IG, Sucipta IW. Karakteristik penderita nodul tiroid yang mendapatkan tindakan operatif di RSUP Sanglah Denpasar periode 2011-2013. Med J. 2017;48(1):72.

[16] Mutalazimah M, Mulyono B, Murti B, Azwar S. Asupan yodium, ekskresi yodium urine, dan goiter pada wanita usia subur di daerah endemis defisiensi yodium. Kesmas Natl Public Heal J. 2013;8(3):137.. 